\title{
Konsep Akad Murabahah Pada Perbankan Syariah (Analisa Kritis Terhadap Aplikasi Konsep Akad Murabahah Di Indonesia Dan Malaysia)
}

\author{
Bagya Agung Prabowo \\ Fakultas Hukum UII Yogyakarta \\ bagya@fh.uii.ac.id
}

\begin{abstract}
There are significant differences in the practice of murabahah scheme between Indonesia and Malaysia. The most distinct feature between them is in the adoption of bai' ail-inah in Malaysia wich is not applicable in Indonesia. National Shariah Council of Indonesia condemns such contract as fraudelent, and hence is fobidden to apply. Here, the contract is designated to be two folds, namely from the bank to customers and from the customers to the bank. Clearly, this a disguised riba. In respect to the fiduciary security (dhaman), there is no difference between the both countries. The reasons for the adoption of the security is for the sake of prudentiality in financing disbursed to the customers.
\end{abstract}

Keywords: Akad, Murabahah, Ba'i al-Inah, Dhaman

\section{Pendahuluan}

Pertumbuhan bank syariah di Indonesia saat ini sangat pesat, seiring dengan tumbuhnya pemahaman masyarakat bahwa bunga (interest) dan modal yang hasilnya telah ditentukan di muka (predetermined return) adalah merupakan riba yang dilarang oleh syariah Islam. Atas dasar pemahaman seperti ini, maka sejak tahun 1950, telah banyak para cendikiawan muslim dan teoritisi ekonomi Islam yang menghendaki keberadaan bank yang terbebas dari bunga atau riba (Interest free banking). ${ }^{1}$ Lembaga perbankan merupakan salah satu lembaga keuangan di Indonesia dijelaskan menurut

${ }^{1}$ Abdullah Saeed, Bank Islam dan Bunga, Studi Kritis dan Interprestasi Kontemporer tentang Riba dan Bunga, Yogyakarta, Pustaka Pelajar ,Ctk. Pertama, 2003, hlm.2 
Undang-Undang No. 7 Tahun 1992 jo. Undang-Undang No. 10 Tahun 1998 tentang Perbankan dan Undang-Undang No. 23 Tahun 1999 jo. Undang-Undang No. 3 Tahun 2004 tentang Bank Indonesia, bahwa lembaga perbankan memiliki fungsi sebagai penghimpun dana dari masyarakat dan menyalurkan kembali dana tersebut kepada masyarakat melalui kredit usaha.

Indonesia dan Malaysia merupakan negara yang menjadi pioner dalam mengembangkan perbankan Islam di kawasan Asia Tenggara. Perkembangan Perbankan Islam di kedua negara cukup pesat, bagaikan jamur yang tumbuh di musim hujan. Perbankan syariah di Malaysia mulai beroperasi sejak tahun 1983 dengan berdirinya BIMB (Bank Islam Malaysia Berhad). Bahkan jika merujuk pada proyek yang diujicobakan pada Lembaga Tabung Haji, Malaysia sebenarnya mulai mengenal lembaga keuangan Islam semenjak tahun 1963, meski eksperimen itu dinyatakan gagal. Sedangkan di Indonesia telah beroperasi 3 bank syariah, 20 bank konvensional yang membuka unit (divisi) syariah dan 105 BPRS, ini belum termasuk BMT dengan peningkatan kualitas yang sangat tinggi (LPPS, 2007). Hal ini pula yang menjadi pertimbangan ditetapkannya UndangUndang Nomor 10 Tahun 1998 tentang perubahan atas Undang-Undang Nomor 7 Tahun 1992 tentang Perbankan yang menyatakan bahwa:

"Bank adalah badan usaha yang menghimpun dana dari masyarakat dalam bentuk simpanan dan menyalurkannya kepada masyarakat dalam bentuk kredit dan atau bentuk-bentuk lainnya dalam rangka meningkatkan taraf hidup rakyat banyak. Bank Umum adalah bank yang melaksanakan kegiatan usaha secara konvensional dan atau berdasarkan prinsip syariah yang dalam kegiatannya memberikan jasa dalam lalu lintas pembayaran".

Perkembangan perbankan syariah di Indonesia begitu cepat dan pesat, namun sebagian masyarakat masih ada yang berasumsi bahwa bank syariah hanyalah sebuah label yang digunakan untuk menarik simpati masyarakat muslim di bidang perbankan. Mereka berpendapat bahwa bank syariah merupakan bank konvensional dengan istilah-istilah perbankan yang menggunakan istilah-istilah Islam, dengan kepala akad yang dibubuhi kalimat Bismillahirrahmaanirrahiim dan pegawai yang mengenakan busana Islami dan mengucap salam, akan tetapi dalam pelaksanaan akad pada bank syariah masih menggunakan cara-cara yang dilarang oleh agama. Sikap skeptis dari masyarakat tentang perbankan 
syariah tersebut tidak dapat dipungkiri karena konotasi perbankan sejak dahulu memang terpisah secara nyata dengan syariah, sehingga pada awal mula pembentukan perbankan syariah banyak yang tidak percaya akan adanya keberhasilan para ekonom Islam dalam menyatukan institusi perbankan dengan syariah.

Salah satu bentuk penyaluran dana pada bank syariah adalah melalui produk pembiayaan murabahah. Murabahah adalah jual-beli barang pada harga asal dengan tambahan keuntungan yang sudah disepakati. ${ }^{2}$ Karakteristik murabahah adalah bahwa penjual harus memberi tahu pembeli mengenai harga pembelian produk dan menyatakan jumlah keuntungan yang ditambahkan pada biaya (cost) tersebut. ${ }^{3}$

Landasan syariah dibolehkannya murabahah adalah QS. An-Nisa': 29, QS. Al-Baqarah: 275 yang artinya sebagai berikut :

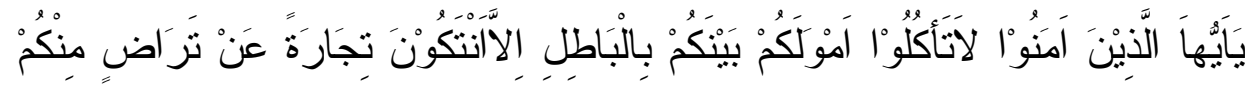

"Hai orang-orang yang beriman, janganlah kamu saling memakan harta sesamamu dengan jalan yang batil, kecuali ada transaksi di antaramu". (QS. An-Nisa ayat: 29)

“... dan Allah menghalalkan jual-beli dan mengharamkan riba”. (QS. Al-Baqarah ayat: 275)

Hadits Nabi Muhammad SAW yang artinya sebagai berikut: Dari Suhaib al-Rumi r.a, bahwa Rasulullah SAW bersabda : "Tiga hal yang di dalamnya terdapat keberkatan : jual-beli secara tangguh, muqaradhan (mudharabah), dan mencampur gandum dengan tepung untuk keperluan rumah, bukan untuk dijual". (HR. Ibn Majah)

Produk murabahah ini merupakan produk pembiayaan di mana pihak bank dapat sebagai mediasi antara pihak yang berkepentingan, yaitu nasabah dan developer atau pemasok, maksudnya dalam hal ini adalah apabila nasabah menginginkan memiliki atau membeli sesuatu barang dari developer sementara nasabah belum memiliki dana yang cukup untuk dapat membelinya, maka bank dalam hal ini memberikan bantuan berupa

${ }^{2}$ Muhammad Syafi'i Antonio, Bank Syariah dari Teori ke Praktik, Ctk. Pertama, Gema Insani Press, Jakarta, 2001, hlm. 101.

${ }^{3}$ Wiroso, Jual-beli Murabahah, UII Press, Yogyakarta, 2005, hlm. 13. 
pembiayaan dengan cara membeli barang yang diinginkan oleh nasabah terlebih dahulu dari developer, kemudian pihak bank menjual kembali barang tersebut kepada nasabah dengan harga sesuai dengan pembelian pihak bank dari pihak developer dengan metode angsuran dan ditambah keuntungan bagi pihak bank yang telah disepakati antara pihak bank dan pihak nasabah sebelum transaksi jual-beli dilakukan.

Keunggulan pembiayaan dari produk murabahah adalah bahwa nasabah dapat membeli sesuatu barang sesuai dengan keinginan, dan kemampuan ekonominya, di samping itu pembiayaannya dilakukan dengan angsuran sehingga tidak memberatkan pihak nasabah itu sendiri adapun keunggulan yang lain adalah bahwa dalam produk murabahah tidak mengenal riba atau sistem bunga tetapi dalam hal ini adanya keterbukaan antara pihak bank dan nasabah bahwa bank sebelumnya memberikan informasi atas barang yang akan dibeli sesuai dengan keinginan nasabah dan harga yang telah ditentukan oleh developer telah diketahui oleh pihak nasabah, kemudian pihak bank menjual kembali kepada nasabah sesuai dengan harga pembelian dari pihak developer, dan ditambah keuntungan bagi pihak bank. Tambahan keuntungan bagi pihak bank ini, diperjanjikan diawal transaksi yang didasarkan atas kesepakatan bersama antara pihak bank dengan nasabah, jadi dalam hal ini tidak terjadi unsur saling mendzalimi.

Transaksi jual-beli pada umumnya dapat dijelaskan mengenai unsur jaminan (dhomman). Kedudukan dhomman dalam transaksi jual-beli secara teori bahwa dhomman hanya sebatas pada penjual bahwa penjual menjamin barang yang dijual tidak adanya cacat tersembunyi. ${ }^{4}$

Menurut mayoritas (jumhur) ahli-ahli hukum Islam, rukun yang membentuk akad murabahah ada lima yaitu : Adanya penjual (ba'i); adanya pembeli (musytari); objek atau barang (mabi') yang diperjualbelikan; Harga (tsaman) nilai jual barang berdasarkan mata uang; ijab kabul (sighat) atau formula akad, suatu pernyataan kehendak oleh masingmasing pihak.

Pembiayaan murabahah memungkinkan adanya dhomman (jaminan), karena sifat dari pembiayaan murabahah merupakan jual-beli yang pembayarannya tidak dilakukan secara tunai, maka tanggungan pembayaran tersebut merupakan hutang yang harus dibayar oleh

\footnotetext{
${ }^{4}$ Hartono Soerjopratiknjo, Aneka Perjanjian Jual-beli, PT. Citra Aditya Bakti, Bandung, 1982, hlm.23.
} 
musytari. Bank syariah $\left(b a^{\prime} i\right)$ memberlakukan prinsip kehati-hatian dengan mengenakan dhomman pada nasabah. ${ }^{5}$

Keberadaan agunan atau dhomman pada bank syariah sekilas memang menjadi permasalahan bagi pihak yang ingin mengajukan pembiayaan, apalagi jika tidak mempunyai dhomman yang dapat dijaminkan untuk memperoleh pembiayaan dari bank syariah. Hal ini menjadi masalah yang berat karena pihak bank syariah akan menyeleksi nasabah dari aspek kelayakan untuk memperoleh pembiayaan baik dari sisi personal ataupun dari sisi finansial, dari sisi personal, biasanya pihak bank syariah akan melihat terlebih dahulu sosok orangnya, apakah orang tersebut mempunyai itikad baik dan layak untuk mendapat pembiayaan atau tidak, sedangkan dari sisi finansial biasanya didasarkan pada kemampuan dalam melakukan pembayaran. ${ }^{6}$

Sebagai salah satu contoh adalah pada pembiayaan murabahah di BTN syariah, terdapat unsur dhomman yang memiliki kedudukan penting di mana dhomman merupakan suatu keharusan, padahal kedudukan dhomman secara teorinya ialah bahwa tidak diperlukannya unsur dhomman pada setiap produk-produk bank syariah karena ketentuan awal bank syariah tidak mengenal dhomman melainkan menggunakan sistem kepercayaan, dan apabila dilihat dari regulasi yang terdapat pada fatwa DSN No. 04/DSN-MUI/IV/2000 terdapat point yang menjelaskan dhomman dalam pembiayaan murabahah dibolehkan, agar nasabah serius dengan pesanannya, jadi bahwa dhomman bisa dijelaskan diperbolehkan untuk mengetahui keseriusan nasabah (musytari) dengan pesanannya terhadap bank $\left(b a^{\prime} i\right)$, tetapi dalam praktik perbankan syariah, adanya dhomman merupakan suatu keharusan dari pihak nasabah, maka implementasinya di perbankan syariah, kedudukan dhomman merupakan syarat wajib pihak bank pada nasabah, apabila akan melakukan suatu pembiayaan.

Berdasarkan uraian tersebut, permasalahan yang menarik untuk dikaji adalah, bagaimana aplikasi konsep akad murabahah pada perbankan syariah di Indonesia dan Malaysia?Bagaimanakah kedudukan dhomman dalam akad murabahah?

${ }^{5}$ Muhammad, Teknik Perhitungan Bagi Hasil dan Profit Margin pada Bank Syariah, Ctk. Ketiga, UII Press, Yogyakarta, 2003, hlm. 110.

${ }^{6} \mathrm{http}: / /$ www.pkes.org/?page=faq-list\&awal=80, diakses 27 Juni 2007, 15:48 


\section{Analisis Aplikasi konsep Akad Murabahah pada Perbankan Syariah di Indonesia dan Malaysia}

Terdapat beberapa perbedaan dalam aplikasi konsep akad murabahah antara Indonesia dan Malaysia. Perbedaan-perbedaan tersebut dapat dilihat dari pemaparan berikut : Akad Murabahah pada bank syariah di Indonesia.

Bank syariah di Indonesia pada umumnya dalam memberikan pembiayaan murabahah, menetapkan syarat-syarat yang dibutuhkan dan prosedur yang harus ditempuh oleh musytari yang hampir sama dengan syarat dan prosedur kredit sebagaimana lazimnya yang ditetapkan oleh bank konvensional. Syarat dan ketentuan umum pembiayaan murabahah, yaitu: ${ }^{7}$ Umum, tidak hanya diperuntukkan untuk kaum muslim saja; Harus cakap hukum, sesuai dengan KUHPerdata; Memenuhi 5C yaitu: Character (watak); Collateral (jaminan); Capital (modal); Condition of economy (prospek usaha); Capability (kemampuan).

Memenuhi ketentuan Bank Indonesia dan pemerintah, sesuai yang diatur dalam Undang-Undang No. 10 Tahun 1998 tentang Perubahan Undang-Undang No. 7 Tahun 1992 tentang Perbankan; Jaminan (dhomman), biasanya cukup dengan barang yang dijadikan obyek perjanjian namun karena besarnya pembiayaan lebih besar dari harga pokok barang (karena ada mark up) maka pihak bank mengenakan uang muka senilai kelebihan jumlah pembiayaan yang tidak tertutup oleh harga pokok barang;

Contoh: Pembiayaan pembelian motor dengan harga pokok senilai Rp.11.000.000,- kemudian sesuai dengan perjanjian pihak $b a^{\prime} i$ menjual kepada musytari senilai Rp. 12.000.000,- dan dibayar ketika jatuh tempo selama satu tahun, maka besarnya pembiayaan tersebut adalah Rp. 12.000.000,- dalam jual-beli ini bisa juga dilakukan dengan prinsip angsuran, jadi musytari setiap bulannya membayar angsuran sebesar Rp. 1.000.000,- jika yang dijadikan dhomman hanya berupa motor tersebut maka ketika pihak musytari wanprestasi dan ketika dijual maka harga pokok motor tersebut tidak akan mencukupi untuk menutup besarnya pembiayaan, maka untuk mengatasi hal tersebut pihak $b a^{\prime} i$ mewajibkan pihak musytari untuk membayar uang muka minimal sebesar Rp. 1.000.000,- pada waktu terjadi akad, atau besarnya uang muka sesuai kebijakan pihak bank.

\footnotetext{
${ }^{7}$ Wawancara dengan Arif Wijaya, Account Officer dari PT. Bank Rakyat Indonesia (Persero) Kantor Cabang Syariah Yogyakarta pada tanggal 20 Mei 2008.
} 
Pembiayaan murabahah yang dilakukan oleh $b a^{\prime} i$ dan musytari adalah perjanjian jual-beli, jika seseorang datang kepada bank syariah dan ingin meminjam dana untuk membeli barang tertentu, misalnya mobil atau rumah, suka atau tidak suka ia harus melakukan jual-beli dengan bank syariah, bank syariah bertindak sebagai $b a^{\prime} i$ dan nasabah sebagai musytari, begitulah cara dari bank untuk memperoleh manfaat (keuntungan) yaitu dari laba penjualan atas barang bukan dari kelebihan yang disyaratkan dalam perjanjian pinjam-meminjam karena bagaimanapun juga bank syariah sebagai lembaga komersial pasti ingin mendapatkan keuntungan. Keuntungan yang diperoleh pihak $b a^{\prime} i$ adalah mark up (laba) dari penjualan barang dalam pembiayaan murabahah. ${ }^{8}$

Besarnya mark up untuk setiap pembiayaan berbeda, besar kecilnya mark up dipengaruhi oleh besar kecilnya risiko yang ditanggung untuk pembiayaan tersebut, besarnya mark up justru tidak dipengaruhi oleh lamanya jatuh tempo pembiayaan seperti yang biasa diterapkan dalam perjanjian kredit pada bank konvensional yang menggunakan prinsip semakin lama suatu kredit yang diberikan maka semakin banyak pula bunga yang didapat oleh pihak bank (time value of money).

Kesepakatan (akad) dalam pembiayaan murabahah ketika telah terjadi, maka besarnya harga sudah tidak dapat berubah lagi, namun untuk menghindari terjadinya wanprestasi oleh musytari yaitu tidak membayar ataupun terlambat mengangsur pembiayaan murabahah maka dalam perjanjian tersebut telah disetujui sebuah klausul tentang pembayaran denda yang harus dibayar oleh musytari ketika musytari terlambat dalam melakukan pembayaran angsuran. Denda yang diterima oleh $b a^{\prime} i$ bukan merupakan salah satu unsur pendapatan bank syariah $\left(b a^{\prime} i\right)$, karena denda yang diperoleh tersebut digunakan sebagai dana sosial yang salah satunya disalurkan melalui Qard al-Hasan, ini adalah salah satu sisi positif perbankan syariah disamping sebagai lembaga komersial perbankan syariah juga berfungsi sebagai lembaga sosial demi kemaslahatan umat.

Pihak musytari dalam pembiayaan ini dimungkinkan membeli sendiri barang yang diinginkan, hal ini terjadi karena pihak musytari memaksa pihak $b a^{\prime} i$ dengan berbagai alasan, misalnya mencari barang dengan harga yang lebih murah, agar mendapatkan diskon, padahal bank syariah sudah menjamin bahwa pihak bank selaku $b a^{\prime} i$ bisa mendapatkan barang dengan

${ }^{8}$ Wawancara dengan Arif Wijaya, Account Officer, dari PT. Bank Rakyat Indonesia (Persero) Kantor Cabang Syariah Yogyakarta pada tanggal 20 Mei 2008. 
harga yang paling murah dan jika ada diskon pun menjadi hak musytari, tetapi bagaimanapun juga sebagai bentuk pelayanan yang memuaskan dan tidak mengecewakan musytari, misalnya untuk menghindari pembelian barang oleh $b a^{\prime} i$ yang tidak sesuai dengan kriteria ataupun spesifikasi yang dikehendaki oleh pihak musytari, maka bank selaku $b a^{\prime} i$ membolehkan musytari untuk membeli sendiri barang yang diinginkan dari supplier dengan cara $b a^{\prime} i$ memberikan kuasa kepada musytari dengan wakalah.

Berdasarkan hal tersebut, seberapa jauh bank syariah selaku $b a^{\prime} i$ dapat mengawasi dan memastikan bahwa dana yang diberikan tersebut benarbenar digunakan untuk pengadaan barang yang sesuai dengan yang diperjanjikan, apalagi terhadap kebutuhan barang yang jenisnya banyak terutama jenis murabahah untuk kebutuhan modal kerja dan keperluan konsumtif. Pada umumnya bank syariah selaku $b a^{\prime} i$ mempunyai kendala teknis terhadap pengadaan barang karena bank syariah tidak mempunyai persediaan barang dan spesialisasi barang yang dijual sementara musytari membutuhkan barang yang beragam jenisnya.

Praktik yang sering terjadi pihak bank syariah tidak murni sebagai penjual barang seperti pada industri perdagangan yang menjual barang secara langsung kepada pembeli, karena pada umumnya bank ( $\left.b a^{\prime} i\right)$ tidak mempunyai persediaan barang, bank juga bukan sebagai agen investasi karena tidak menawarkan barang yang menjadi obyek jual-beli.

Sebagai gambaran tentang praktik pembiayaan murabahah di bank syariah pada umumnya di Indonesia, Penulis akan memaparkan beberapa contoh bentuk pembiayaan murabahah yang biasa dilakukan oleh bank syariah, yaitu sebagai berikut: (a) contoh akad pembiayaan murabahah untuk perbaikan atau renovasi rumah, yaitu sebagai berikut: musytari yang akan mengajukan pembiayaan renovasi sebuah rumah ketika telah disetujui maka pihak bank ( $\left.b a^{\prime} i\right)$ akan memberikan dana yang kemudian dengan sebuah surat kuasa dari $b a^{\prime} i$, musytari diberi amanah untuk membeli bahan-bahan bangunan yang dibutuhkannya dengan mekanisme yang dapat dilihat dalam gambar 1.1, dengan syarat selama 30 (tiga puluh) hari musytari tersebut sudah membeli bahan-bahan bangunan yang ditunjukkan dengan bukti pembelian berupa nota ataupun faktur. Hal ini terjadi karena menurut pihak bank selaku $b a^{\prime} i$ akan sulit sekali apabila $b a^{\prime} i$ yang melakukan pembelian sendiri atas barang-barang yang diperlukan dalam renovasi rumah tersebut; (b) contoh akad pembiayaan murabahah untuk pembelian sebuah mobil, yaitu sebagai berikut: berbeda 
dengan pembiayaan murabahah untuk renovasi rumah, untuk pembelian mobil karena obyeknya (mobil) jelas, pasti dan diketahui secara jelas siapa pemiliknya (supplier) maka pihak $b a^{\prime} i$ akan secara langsung menghadirkan supplier (penjual mobil) tersebut dalam akad yang akan dilaksanakan antara $b a^{\prime} i$ dan musytari, artinya pihak $b a^{\prime} i$ secara langsung akan memberikan uang kepada supplier (pemilik mobil) sebagai pemilik mobil tersebut yang kemudian akan dilaksanakan akad jual-beli antara $b a^{\prime} i$ dengan musytari dalam akad murabahah, meskipun secara langsung bukti kepemilikan barang dari pihak pemilik mobil langsung diserahkan kepada musytari dan kepemilikan langsung berpindah dari pemilik (supplier) ke musytari, seperti yang dapat dilihat pada gambar 1.2, secara teori dan pelaksanaannya, skema kedua inilah yang sesuai dengan Fatwa Dewan Syariah Nasional yang dijadikan dasar hukum akad murabahah dalam perbankan syariah; (c) contoh akad pembiayaan murabahah untuk pembelian sebuah rumah (pembiayaan KPR oleh bank syariah sebagai contoh BTN Syariah) ${ }^{9}$ yaitu sebagai berikut: untuk kepentingan musytari pihak bank $\left(b a^{\prime} i\right)$ terlebih dahulu membeli rumah (yang dibutuhkan musytari) dari penjual atau developer untuk kemudian menjual kembali kepada musytari sebesar harga beli dari developer ditambah sejumlah keuntungan yang dimintakan oleh bank dan disetujui atau disepakati oleh musytari; (d) contoh akad murabahah untuk persediaan modal kerja (modal kerja barang) seperti peralatan pabrik, sama seperti akad pembiayaan murabahah pengadaan barang lain pada umumnya, yaitu bank (ba'i) membelikan terlebih dahulu barang tersebut dari supplier kemudian $b a^{\prime} i$ menjual barang tersebut pada musytari melalui akad murabahah dengan harga sebesar harga pokok ditambah keuntungan yang telah disepakati antara $b a^{\prime} i$ dan musytari;

${ }^{9}$ Wawancara dengan Hanan Wihasto, SE,M.M, Kacab BTN Syariah Cabang Yogyakarta, pada tanggal 21 Mei 2008. 
Bagan 1: Mekanisme pembiayaan murabahah melalui wakalah/perwakilan

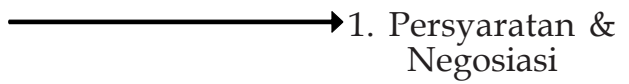

2. Akad Murabahah

3. Menyerahkan dana \& Memberikan kuasa

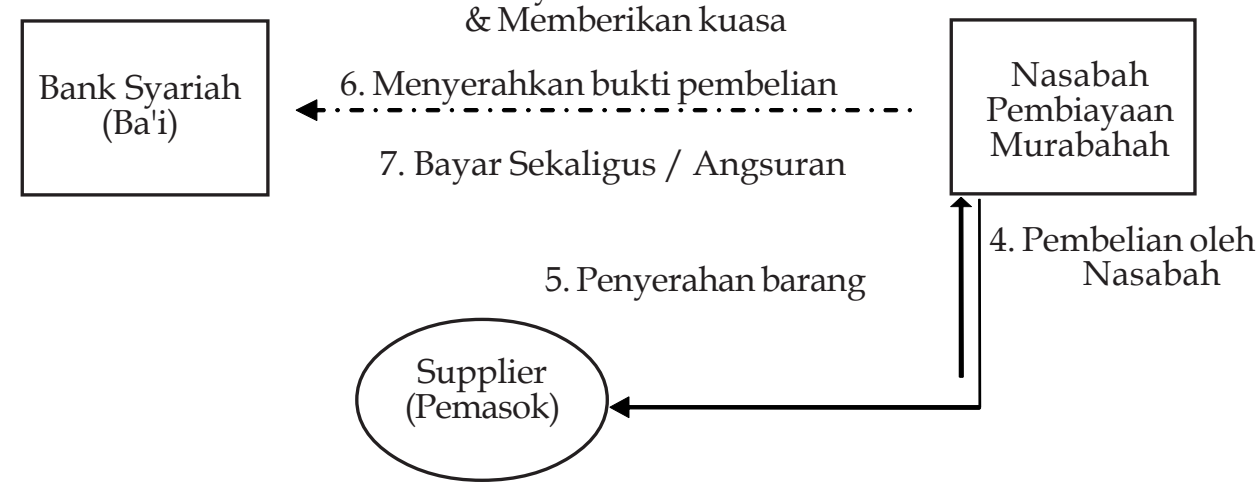

Bagan 2: Mekanisme pembiayaan murabahah secara langsung

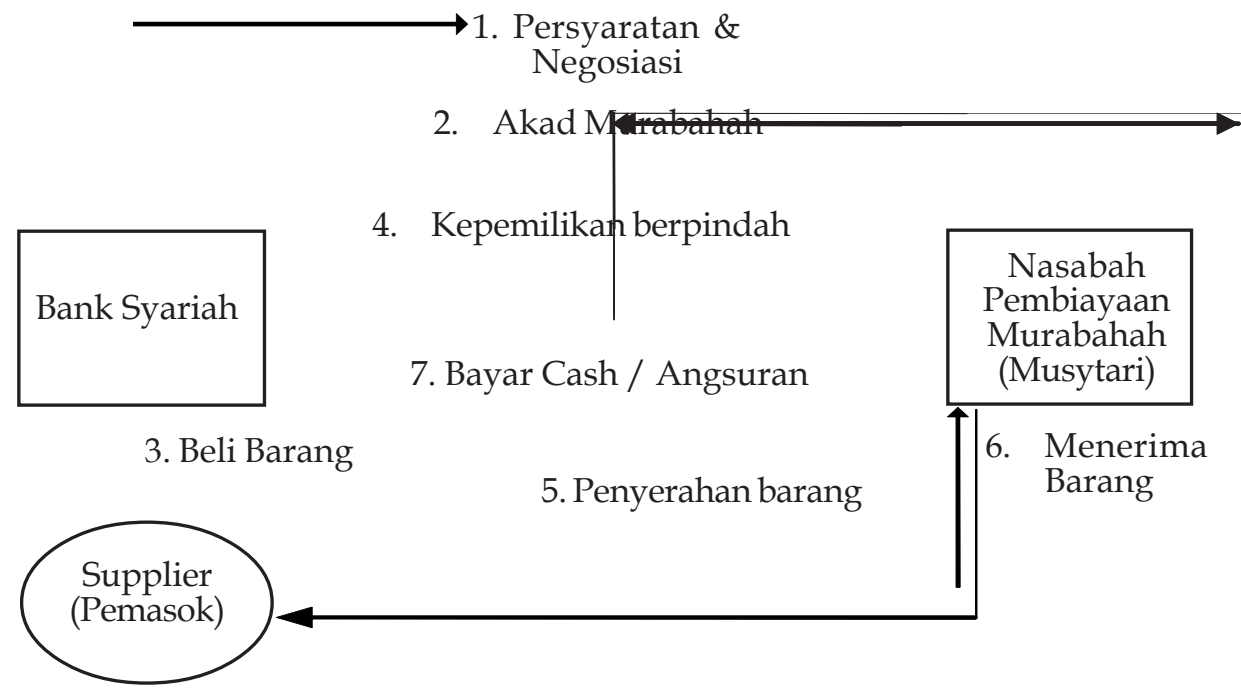

Keterangan sebagai berikut: (1) calon musytari membutuhkan barang namun tidak/belum mempunyai dana tunai kemudian mengajukan pembiayaan murabahah pada bank syariah, setelah musytari memenuhi persyaratan pengajuan permohonan, terjadi negosiasi margin antara musytari dengan $b a^{\prime} i$; (2) setelah proses negosiasi dan terjadi kesepakatan bersama maka terjadi akad murabahah; (3) ba'i membeli barang sesuai yang diinginkan oleh musytari sebagaimana yang telah menjadi kesepakatan 
dalam akad murabahah; (4) ketika terjadi akad maka kepemilikan barang langsung berpindah dari ba'i kepada musytari; (5) penyerahan atau pengiriman barang dari supplier kepada musytari, dalam hal ini tidak perlu harus melalui $b a^{\prime} i$ tetapi langsung kepada musytari kecuali diperjanjikan lain; (6) pihak musytari telah menerima barang dan sesuai dengan yang telah disepakati; (7) musytari akan membayar/mengembalikan dana berupa harga pokok ditambah dengan margin keuntungan yang telah disepakati baik secara sekaligus saat jatuh tempo maupun secara angsuran.

Berdasarkan hal-hal tersebut di atas, peran bank selaku $b a^{\prime} i$ dalam pembiayaan murabahah lebih tepat digambarkan sebagai pembiaya dan bukan penjual barang, karena bank tidak memegang barang, tidak pula mengambil risiko atasnya. Kerja bank $\left(b a^{\prime} i\right)$ hampir semuanya hanya terkait dengan penanganan dokumen-dokumen. Kontrak murabahah umumnya ditanda-tangani sebelum $b a^{\prime} i$ mendapatkan barang yang dipesan oleh musytari, dalam kontrak tersebut musytari lah yang harus berhati-hati dan mematuhi hukum dan aturan yang terkait dengan pengiriman barang, rasio laba, dan spesifikasi yang benar. Musytari sendirilah yang menanggung semua tanggungjawab atas denda atau sanksi hukum yang diakibatkan dari pelanggaran hukum tersebut. $B a^{\prime} i$ tidak berkeinginan memikul tanggungjawab yang terkait dengan barang, karena itu segala risiko yang terkait dengannya yang secara teoritis harus ditanggung $b a^{\prime} i$, secara efektif telah terhindarkan. Musytari menyelesaikan kerugian tersebut bukan dengan $b a^{\prime} i$ akan tetapi dengan pihak supplier.

\section{Akad Murabahah pada Bank Syariah di Malaysia}

Berbeda dengan bank syariah di Indonesia yang menggunakan akad murabahah dalam transaksi jual-beli sebagai salah satu bentuk produk pembiayaan, di negara Malaysia produk ini lebih banyak diterapkan menggunakan akad $b a^{\prime} i$ Inah. ${ }^{10} B a^{\prime} i$ Inah secara umum dapat digambarkan sebagai berikut : Salah satu bank Islam di Malaysia menjual barang dagangannya kepada nasabah (customer) dengan harga yang sudah disepakati yaitu RM 50.000 dan diangsur sampai batas waktu tertentu, lalu bank membelinya kembali dari customer dengan harga yang lebih murah yaitu RM 40.000. Dengan demikian, barang dagangan semula tetap kembali ke pihak penjual.

${ }^{10}$ Siti Murtiyani, Akademisi dan Konsultan Hukum Perbankan Syariah (sedang tempuh S3 di Malaysia), melalui e-mail pada tanggal 2 Juni 2008. 